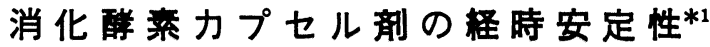

\author{
永瀬一郎*a，藤代とし，岡本尚子，金久保好男 \\ 千葉大学医学部付属病院薬郕部水
}

\section{Change with Time in Activity and Dissolution of Digestive Enzymes in Capsule*1}

\author{
ICHIRO NAGASE*a, TOSHI FUJISHIRO, TAKAKO \\ OKAMOTO, and YoSHIO KANAKUBO \\ Hospital Pharmacy, Faculty of Medicine, Chiba University*2
}

(Received October 20, 1979)

\begin{abstract}
Six brands of multiple digestive enzyme capsules were tested for their stability of weight, disintegration of capsules, enzyme activity and dissolution in the solutions of $\mathrm{pH}$ 6.5, 5.0 3.0, and the 2nd fluid of J. P. IX after storage in press-through pack (PTP) at room temperature for one year. After storage, properties of some preparations were degraded. When stored in simple packs prepared by the manufacturers, the preparations maintained better stability than the storage in PTP, though slightly degraded in quality.

$\mathrm{AC}$ and PT were tested for the change with time in their activity and dissolution through the storage at $30^{\circ}, 80 \% \mathrm{RH}$, and at $35^{\circ}, 80 \% \mathrm{RH}$ in and out of PTP. At $30^{\circ}$, their enzyme activity seemed to be stable for 4 weeks, though the color and odor of the content of capsules increased gradually. Acid resistance of enteric coating of PT, which was initially excellent, was gradually lowered. After storage for 6 weeks at $35^{\circ}, \mathrm{AC}$ and PT changed solubility of capsules, and their odor became practically intolerable.
\end{abstract}

市販総合消化酵素製剤については，その酵素活性，耐 酸・溶出性に関してて多くの報告がなされており，著者ら も前報 ${ }^{1 \sim 3)}$ そおいてそれらの酵素活性および溶出性につ いて各製剤の特徵ならびそロット間の活性比較を行っ た.これらの製剤はすべてその添付文書に保存法に注意 するよう記載されており，また使用期限が製造後 30 力月 とされているすのるある.

総合消化酵素製剂の経時安定性に関しては，主に過酷 条件における䤃素活性の変化についての報告が散見され る4 b)が，通常調剂室保管や在庫時にはPTP または包装 のまま室温で保存されていると思われるため，今回著者 らは既報の消化酵素製剤について，PTP で室内 1 年保 存と包装のままの保存とを行い, また夏季の調剤室およ

*1 本報を「消化醅素郕の酵素活性について」第 4 報と する。

*2 千葉市亥鼻 1 丁目8-1；8-1, Inohana 1-chome, Chiba-shi, 280 Japan

*a 現 ; 東京用信病院薬剤科
び患者交付後の保存に対応するものとして，30，80\% $\mathrm{RH}$ と $35^{\circ}, 80 \% \mathrm{RH}$ の保存をむ行って, 酵素活性および 溶出性に関する経時安定性を検討したので報告する.

\section{実 験 の 部}

\section{1. 試料}

試料は前報1,2) と同じ市販総合消化酵素カプセル 剤 6 種, AC(Lot No. T90168 NL), SE (Lot No. 846-3), ST (Lot No. XT149), SV (Lot No. SVPG 462), TE (Lot No. W1919Y), PT (Lot No. OM1077)を用い た.

\section{2. 経時安定性試験保存条件}

\section{A 害温保存}

a）包装を開きPTP シールのままボール箱に入れ，室 温, 室湿度で 1 年間保存した後, 重量, 力価測定, 崩壊 試験, 溶出試験を行った。（以下 PTP 1 年保存と略 す.)

b）メーカーによるPTP10シートずつのプラスチック 
あるいはメタルパックのまま，粸入時に入ってきた缶あ るいは箱に入れ, 室内に製造後 30 力月に至るまで保存 し, PTP 1 年保存と同様に試験を行った.なお゙ハック内 にはいずれる乾燥剤が入れられていた。（以下パック保 存と略す.)
Table 1 亿各試料の包装形態を, Fig. 1 飞PTP 1 年 保存中の自記温湿度計による気温, 湿度の変動と各試料 の保存期間を示した. パック保存も同様の条件下で行っ た. 室内には夏期はェアコンディショナー, 冬期はスチ ームが通っていた。

Table 1. Packages and Containers of Tested Preparations

\begin{tabular}{ccccc}
\hline \hline Preparation & Capsule Size & Sheet & Package & Container \\
\hline A C & No.I & PTP(10cap.) & Metal pack(50sheets) & Cardboard box(10packs) \\
S E & No.I & PTP(10cap.) & Plastic pack(10sheets) & Can(50packs) \\
transparent & loose & \\
S T & No.I & PPP(10cap.) & Metal pack(10sheets) & Cardboard box(10packs) \\
S V & No.I & PTP(12cap.) & Plastic pack(10sheets) & Can(10packs) \\
T E & No.0 & PTP(10cap.) & Plastic pack(10sheets) & Can(10packs) \\
P T & No.I & PTP(10cap.) & Metal pack(10sheets) & Cardboard box(10packs) \\
\hline
\end{tabular}

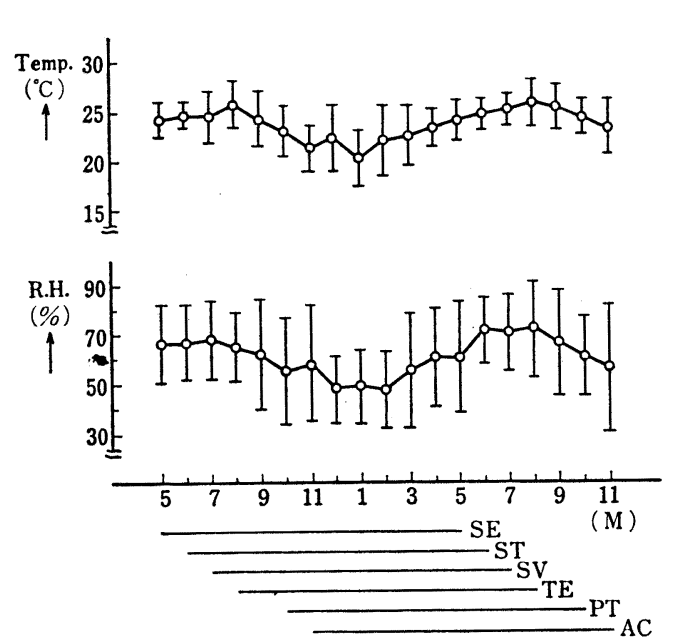

Fig. 1. Room Temperature and Relative Humidity during the Storage

\section{B $30^{\circ}$ および35゚保存}

前報1,2)で良好な結果を示し,かつ腸溶顆粒の溶出性の 異なっていたA C, P Tについて, $30^{\circ}, 80 \% \mathrm{R} \mathrm{H}$ ，これ よりも過酷な条件として $35^{\circ}, 80 \% \mathrm{R} \mathrm{H}$ を選び保存試験 を行った. 試料はPTPシールのままとシールから取り出 してバラカプセル剤としたものとについて,それぞれ $30^{\circ}$ および $35^{\circ}$ のふ卵器内に設置した塩化アンモニウム飽和 溶液入りのデシヶーター中で 4 ～週間保存した。重 量, 力価測定, 崩壊試験はセット時と $1,2,3,4,6,8$ 週間後に行い, 溶出試䭆は PTP. $30^{\circ}$ 保存のものは 3,4
週間後, バラ $30^{\circ}$ 保存のものは 2,4 週間後, PTP $35^{\circ}$, バラ35保存のものは $2,4,8$ 週間後に行った.

\section{3. 五年偏美試験}

試料を室温保存時は 40 個, $30^{\circ}$ およ゙ $35^{\circ}$ 保存時は 20 個 とり, カプセル剂の重量拈よびその内容物の重量を 1 個 ずつ直示天种（安並Y T-2 形)で量り, それぞれについ て平均, 標準偏差, 变動係数を算出した。

\section{4. 崩燷試験}

JP IX 崩壊試験法にしたがい, 6 カプセルが全部崩壊 し終わる時間を測定した.

\section{5. 䆏素活性測定法}

酵素活性の測定および力価の算出は前報1 と同様に 行 った.

a) アミラーセ作用 $\mathrm{pH}$ 5.0亿括いて可溶性デンプン （和光純薬：デンプン〔溶性〕）を基質とし,デンプン糖 化力を銅試薬法 ${ }^{7,8)}$ に準じて測定した。

b) プロテアーセ作用 $\mathrm{pH} 3.0$ および $\mathrm{pH}$ 7.0とおいて ミルクカゼイン(E. Merck : Casein nach Hammarsten) を基質とし，カゼインーフォリン比色法 ${ }^{9}{ }^{100}$ と準じて測 定した.

c）リパーゼ作用 $\mathrm{pH} 7.0$ と打いてオリブ油（丸石製 薬：日局）乳液を基質とし，山田らの方法 ${ }^{11}$ に準じて測 定した.

d） セルラーぜ作用 $\mathrm{pH} 4.0$ 亿执いてカルボキシ チルセルロースナトリウム（第一化学薬品）を基質とし 百瀬法 ${ }^{12,13)}$ に準じて測定した。 


\section{6. 溶出試殹}

前報 ${ }^{3)}$ と同様に行った。

a）沼出液 JP IX第 2 液 $(\mathrm{pH} 7.5)$ ，および第 1 液と 第 2 液の混合による $\mathrm{pH} 3.0 ， 5.0 ， 6.5$ の液を用いた。

b) 試験法 JP IX 崩壊試験器（富山産業 T-2 H）を 用い, 試料カプセルの内容物について $\mathrm{pH} 5.0,6.5$ 溶出液 中では120分間, $\mathrm{pH} 3.0$ 溶出液中では120分間と引き続き 第 2 液中に移して60分間上下運動を行い，一定時間ごと に一定量の溶出液を採取して, ハパーゼとプロテアーゼ

(pH 7.0) 活性を測定した. $30^{\circ}$ 执よび35保存時は pH6.5 溶出液での試験は省略した。

\section{突験詰果むよび考㳟}

\section{A 室温保存}

1. 五五侢美 カプセル剂重量と内容物重量の変化は 平行し，パック保存では 6 製剤とす重量変化ははとんど なく, PTP 1 年保存では S E, S V は変化なく, S T, T Eがやや増加， P Tは 4\%，A C $5 \%$ の増加を示し た(Table 2).

2. 外斑变化 カプセル斉の外観にはいずれる変化が みられなかったが，内容物はパック保存でやや濃色化が 認められたものがあり，PTP 1 年保存では濃色化ととも に特異臭も強くなっていた.

Table 2. Weight Variation of Capsules and Their Contents $(n=40)$ and Disintegration Time of Capsules after Storage at. Room Temperature

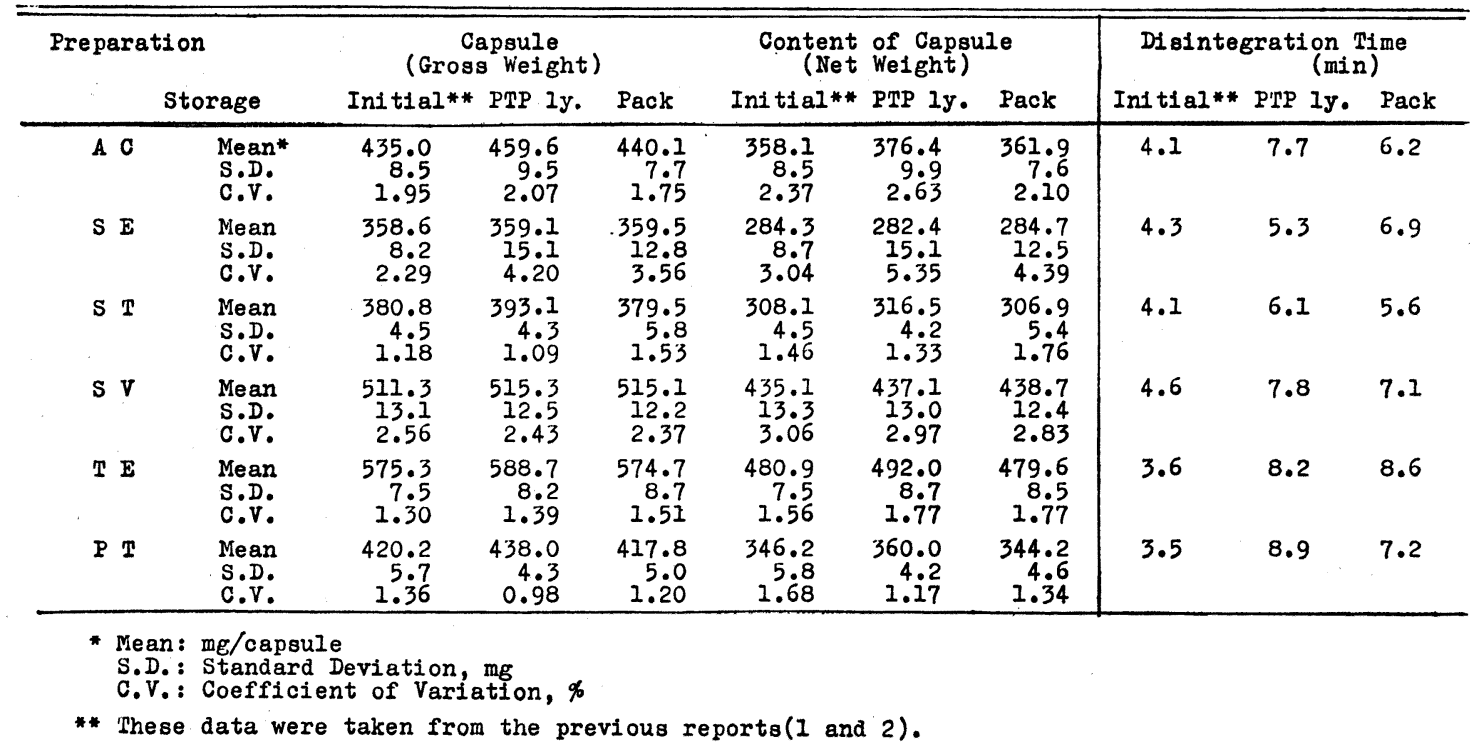

3. 崩壊試験 内容物に粉末を含むA C, S E, S Vは PTP 1 年保存ではかたまって分散し難くなり，また顆 粒やミニペレットのみの S T, T E , P T の PTP 1 年保 存および 6 製剤のパック保存も購入時と比較すると, 内 容物がディスク裏面や網目に粘着し易くなってバラッキ が多くなり崩壊時間が幾分延長したが，JP IXの崩壊試 験には適合した.PTP 1 年保存の崩壊後の試験液はやや 濃色となり，臭気も強くなっていたＳＥのパック保存 は終了後の試験液中に膨潤した透明薄皮様物質の小片が 認められ，PTP 1 年保存ではより大きな片が浮遊してい た. S T, S Vでは PTP 1 年保存にこの小片の浮遊を認 めたが，パック保存では認められず，A C, T E, P Tで は両保存ともこれら小片の浮遊は認められなかった。
本試験とは別に, PTP保存の 6 製剤の内容物を取り除 いた空カプセルについて, 1 個を $100 \mathrm{ml}$ の水または第 1 液中に入れ，37\%の水浴中で振りまぜたところ， A C , T E，P Tでは溶解したが，S E，S T，S Vでは透明な 薄皮様物質の小片が残留していた。これらから，崩壊試 験でみられた薄皮様小片はカプセルに由来すると思わ れ, カプセル自体の経時変化も考慮されなければならな いと思われた。

4. 製剂の醇素活性 前報1)で得た購入時の酵素力価 に対する経時保存後の各酵素力価の変動を Fig. 2 に示 した. PTP 1 年保存では, アミラーゼ活性が S E, S T で30〜35\%，プロテアーゼ(pH 7.0)活性が S Eで30\%， リパーゼ活性が T E で 40\%，セルラーゼ活性がS Tで 
28\%低下し，パック保存ではリパーゼ活性がT Eで35\% の低下を示したほかは，10２0\%低下のもの若干で，ほ とんどが 10\% 以下の変動であり, 酵素活性の変化は少
ないものと思われた．低下のみられたものについても製 剂間の各酵素作用の活性比が大きいため, その相対的活 性順位には著しい变化はみられなかった。

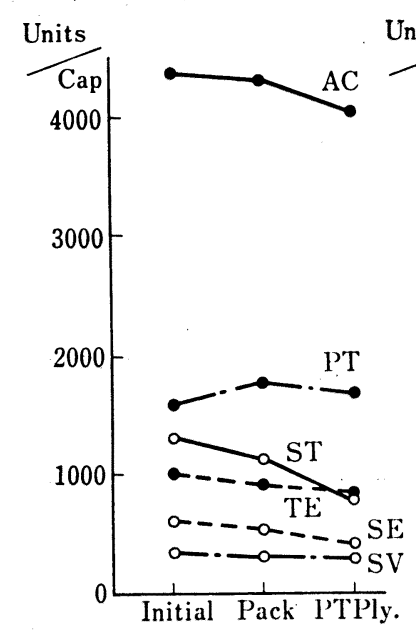

Amylase (pH5.0)

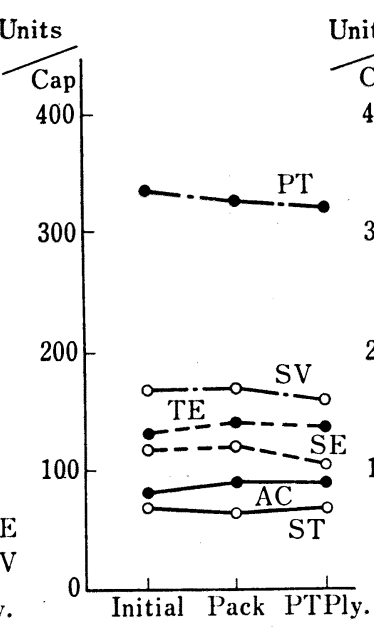

Protease $(\mathrm{pH} 3.0)$

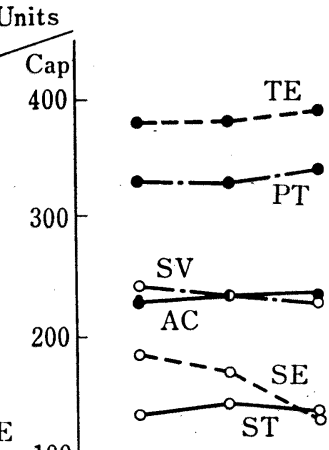

100

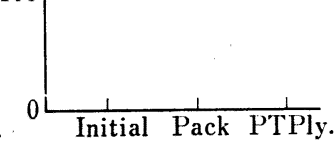

Protease (pH7.0)
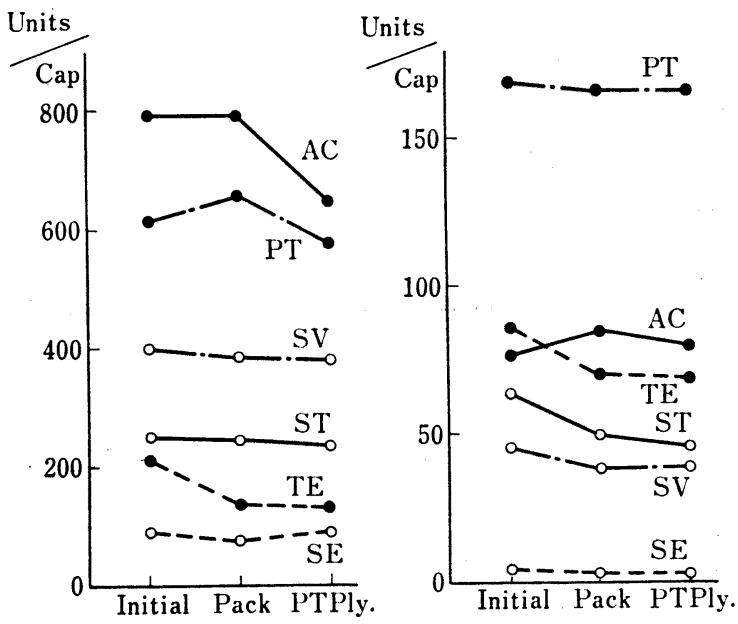

Lipase (pH7.0)

Cellulase $(\mathrm{pH} 4.0)$

Fig. 2. Change of Enzyme Activities after Storage at Room Temperature 


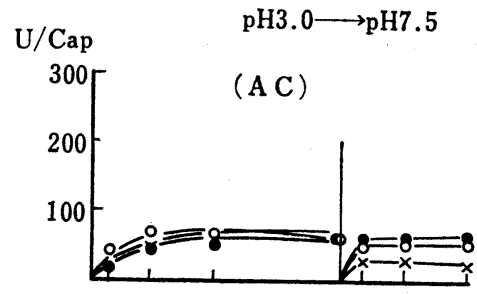

( $\mathrm{S} \mathrm{T})$
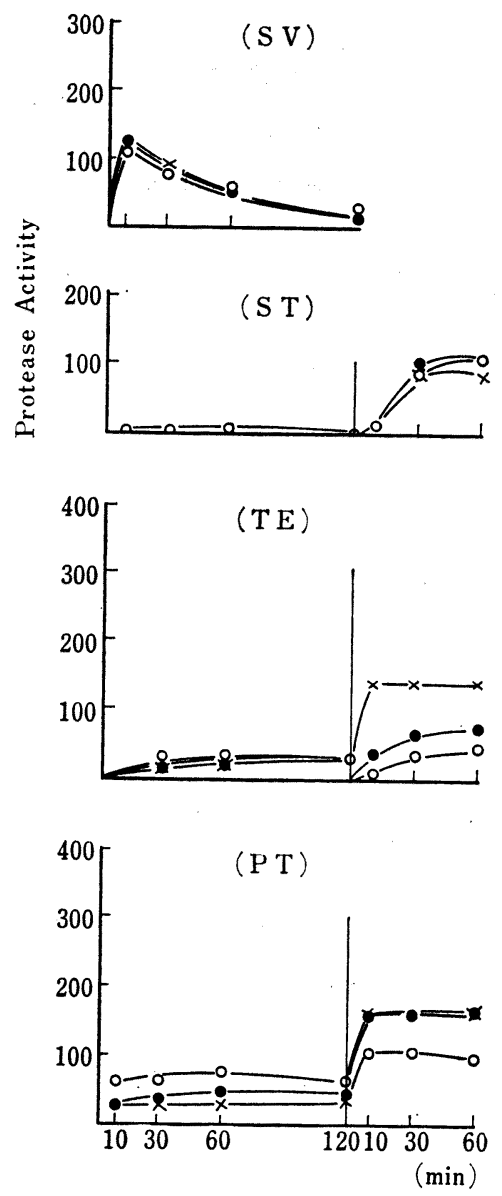

$\mathrm{X} \longrightarrow \mathrm{X}$ Initial,

Fig. 3. C
pH5.0
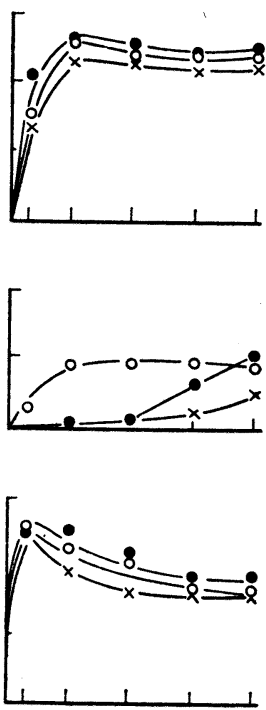

pH6.5
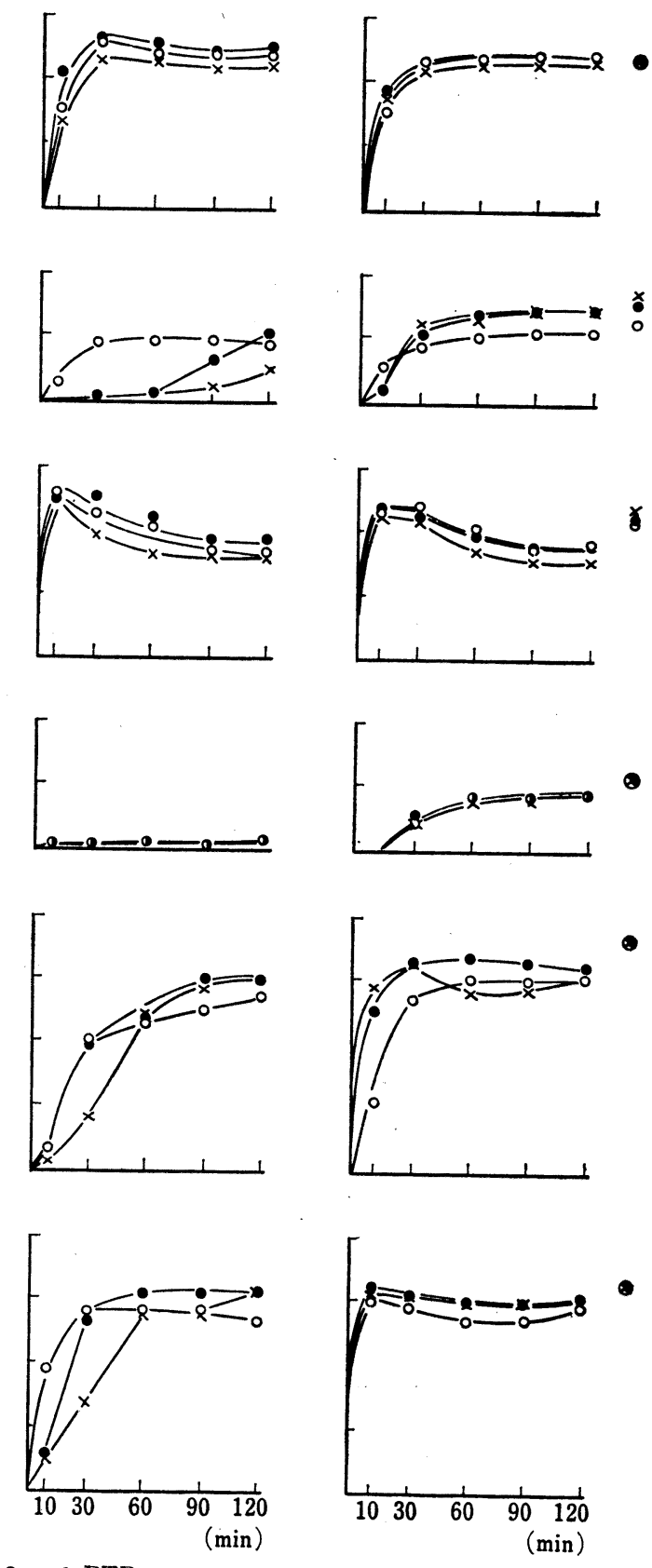

. Change of the Dissolution Curve of Protease( $\mathrm{pH7.0)}$ after Storage at Room Temperature 

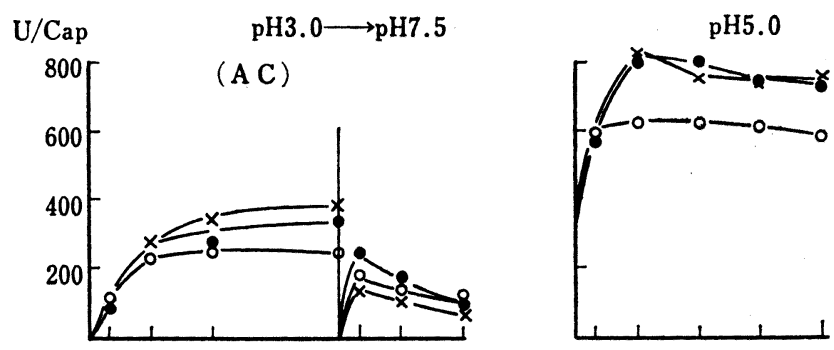

$\mathrm{pH} 6.5$
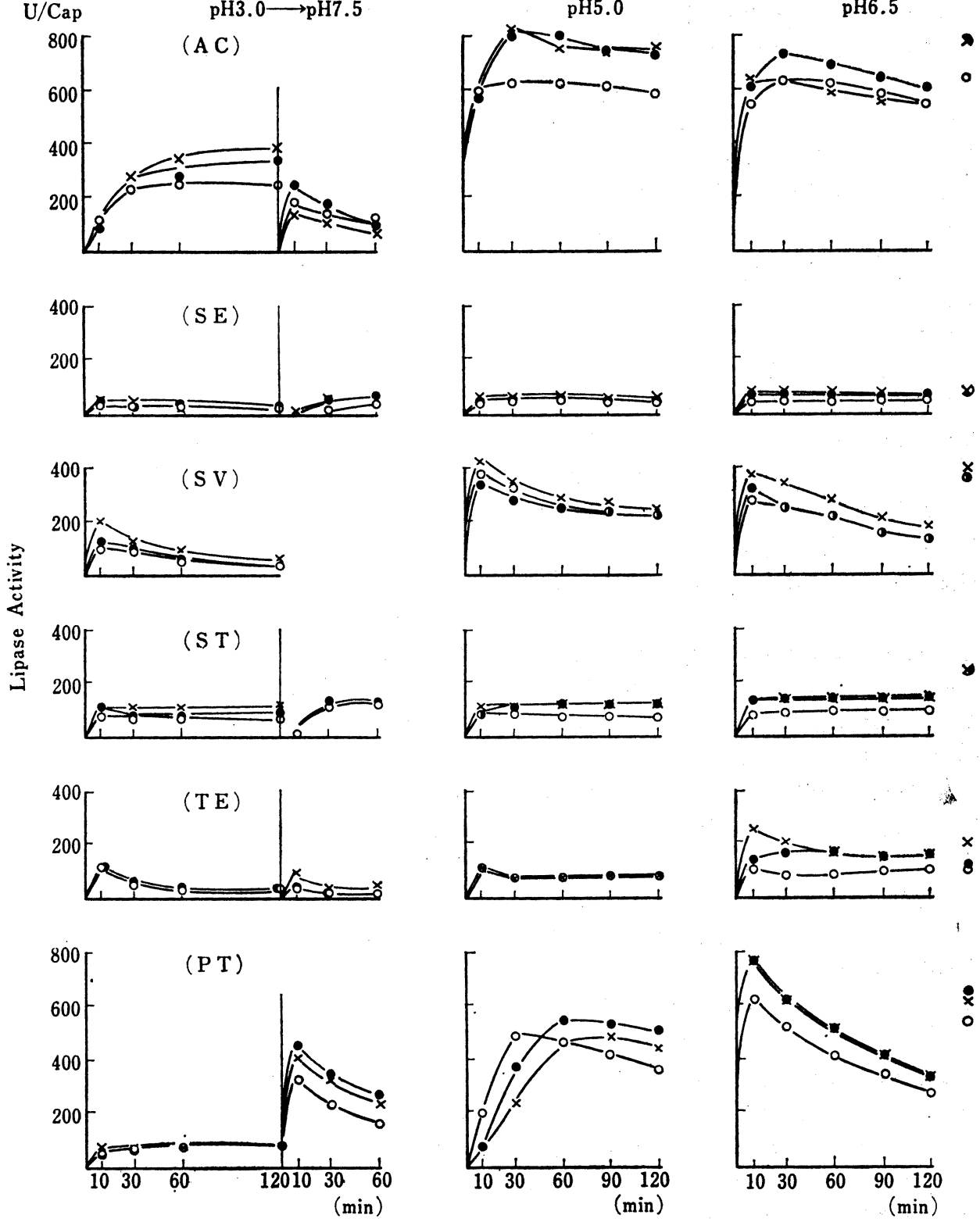

$x \longrightarrow x$ Initial,

○— PTP,

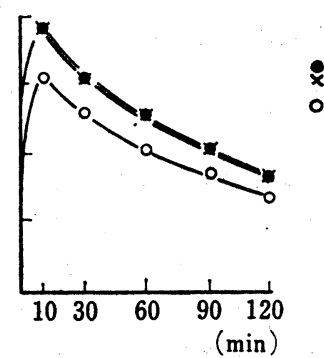

Fig. 4. Change of the Dissolution Curve of Lipase(pH7.0) after Storage at Room Temperature 
5. 睹案溶出性 Fig.3，4 は6 製剂の PTP 保存，パ ック保存の各 $\mathrm{pH}$ 溶出液に拈けるプロテアーゼ( $\mathrm{pH} 7.0)$, リパーゼの溶出活性を購入時2) のそれと対比したもので あり，右端にそれぞれの力価を示した。

A C , S V, S T : PTP 1 年保存のリパーゼ活性が幾 分低下したが，プロテアーゼ (pH7.0) 活性や溶出パター ンは余り変わらず, パック保存ではほとんど变化は認め られなかった．SE：リパーゼ活性が PTP 1 年保存で やや低下していた. プロテアーゼ (pH7.0) 作用は活性の 若干の低下に加えて溶出パターンにも変化がみられた。 $\mathrm{pH} 3.0$ 溶出液において購入時にはほとんど認められなか った溶出活性が，外観上皮膜の溶解はみられなかったに もかかわらず30分後に約 $25 \%$ みられた反面, 第 2 液に移 した際には低下しており，その60分後の筒内には膨潤し た暗灰色糊状物質を残留していたまた $\mathrm{pH} 5.0$ 溶出液で は購入時は 90〜120 分まで認められなかった溶出の立ち 上りが，パック保存で $60 \sim 90$ 分と早くなり，PTP 1 年保 存ではさらに速やかで30分後にはすでに溶出を終了して おりり, 腸溶皮膜の耐酸性および腸溶性の劣化が推測され た.

T E : 溶出パターンに変化がみられた。 pH 5.0 溶出液 でプロテアーゼ (pH7. 0) の活性はパック保存, PTP 1 年保存の順に溶出の立ち上りが早くなり, 第 2 液および $\mathrm{pH6.5}$ 溶出液ではリパーゼ, プロテアーゼ(pH7.0)活性に 溶出の遅れと低下がみられた．PTP 1 年保存では, 第 2 液中で溶解性を減して半透明糊状となった腸溶皮膜が試 験器の上下運動にしたがい筒内で平板状となって褐色内 容物を中心に包み込んでしまい，ために酵素の溶出が妨 げられたものと思われ, 皮膜の耐酸性の低下に加えて腸 溶性の劣化が推測された。

P T : 溶出パターンに変化がみられた. PTP 1 年保 存のプロテアーゼ(pH7.0)活性はpH3.0溶出液で購入時に 比し約 2 倍の溶出がみられた反面, 第 2 液では低下して おり，また pH 5.0溶出液に和けるリパーゼ, プロテアー ゼ(pH 7.0)活性は, 購入時には60分を要した溶出立ち上 りがパック保存で 30 ～ 60 分となり，PTP 1 年保存では さらに速やかになり腸溶皮膜の耐酸性の低下が推測され た. 以上のように腸溶皮膜は経時変化を受けて, ハッック 保存, PTP 保存の順にS E, T E , P T では耐酸性が低 下して低 $\mathrm{pH}$ においてすでに腸溶性成分の溶出が始まり, S E, T E では腸溶性が劣化して腸溶性成分の溶出が妨 げられたものと思われる。

\section{B $30^{\circ}$ おび35。保存}

1. 五专偏童 カプセル剂重量と内容物重量の変化は ほぼ平行して推移し, PTP 保存の重量増加は小さく $30^{\circ}$
と 35 保存でも 4 〜 週間でA C, P T とも約 $6 \%$ 程度で あり, 温度による差はわずかであった. バラ保存は PTP 保存よりも，また $35^{\circ}$ 保存では $30^{\circ}$ 保存よりも重量増加は 大きく，特に初めの 1 週間の増加率が大であった．平均 重量はバラ $35^{\circ} 8$ 週間保存で A Cは 6〜8\%, P Tは 7 〜10\%增加していた. 各時点での標準偏差, 变動係数は $\mathrm{AC} ， \mathrm{PT}$ Tもセット時のそれらとの間に差が認められ なかった.

2. 外镜変化 カプセル斉の外観は ACはこれらの条

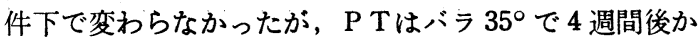
ら白色ボディを透かして濃色となった内容物の顆粒がま たらに見えるようになった。内容物は A C , P T とも PTP $30^{\circ}, 35^{\circ}$ およ゙゙ジ $30^{\circ}$ 保存下では経時的にやや 濃色化し, 臭気も少し増加した程度であったが, バラ $35^{\circ}$ 保存では A C 1 週間後にはやや濃色が認められ内容粉 末はかたまり気味となり，6 週間後には初め白茶色であ ったピルと粉末が黄褐色となった． P T も 1 週間後から 変色が始まり，2 週間後には顆粒相互の粘着もみられ， 4 週間後には初め淡褐色であった顆粒は焦茶色となり, 6 週間後には黒褐色となり顆粒相互のかたまりができ臭 気も強くなった， AC, PT とも吸湿の進行とともに腸溶 ピルや顆粒は乳鉢で粉砕してもつぶれるのみで粉末とは ならなくなった。 バラ $35^{\circ} 6$ 週間以降は両製剤ともカプ セルのままでも特異臭が強く服用にはちゅうちょするも のと思われた。

3. 崩溒試験 $30^{\circ}$ 保存はバラ, PTP と崩壊に際 してカプセル中央の重なり部分や内容物がディスク裏面 や網目に粘着したため時間が多少延長した程度であった が, 350保存はバラ, PTP ともに 6,8 週間後では試験 液は濃色となりカプセルはやや溶解性を減じて薄皮様小 片の浮遊が認められた. 崩壊時間はいずれる若干延長し たが，すべて JP IX の崩壊試験には適合していた.

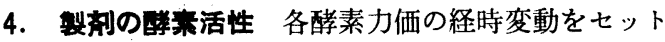
時の力価に対する残存率として保存条件ごとにまとめ Fig. 5 に示した.

アミラーゼ活性は，ACは変化が少なかったが P Tは バラ $35^{\circ} 8$ 週間保存後 $40 \%$ 近い低下を示した. プロテア 一ゼ活性は A C , P T と 4 条件下で大きな変化はみら れなかった。リパーゼ活性は A C , P T とも350保存で低 下傾向にあり, バラ $35^{\circ} 8$ 週間後には A C, P T と約 $40 \%$, PTP $35^{\circ} 8$ 週間後では30〜35\%の低下を示した. セルラーゼ活性はA C は変わらなかったが, P TはPTP $35^{\circ}$, バラ $35^{\circ}$ 保存ともに経時的に低下し，8週間後には バラでは 45\%, PTP で 35\%はでの低下を示した. 以上 酵素活性は 2 製剤とも $30^{\circ}$ 保存で PTP, バラ 4 週間は安 
A C

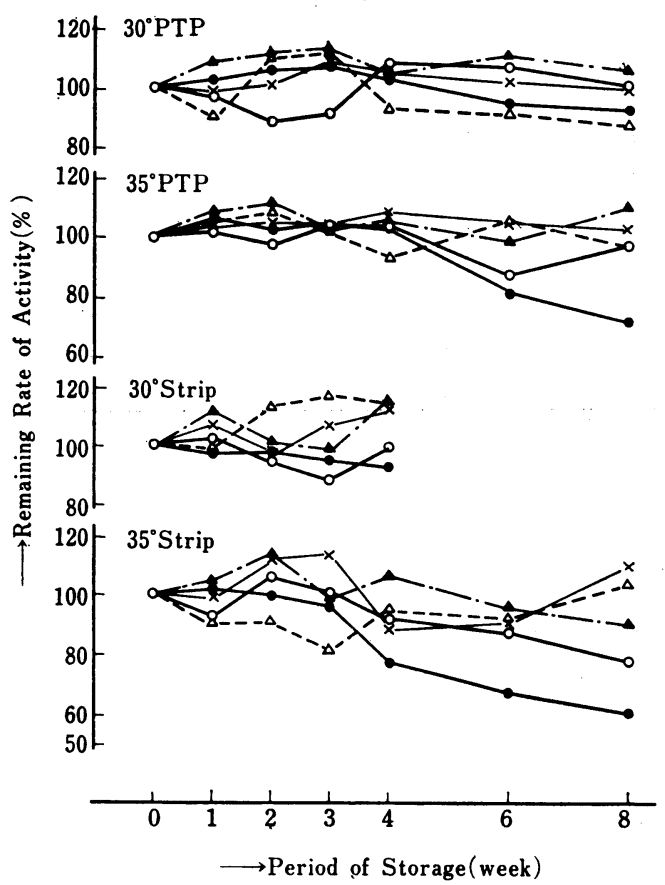

P T
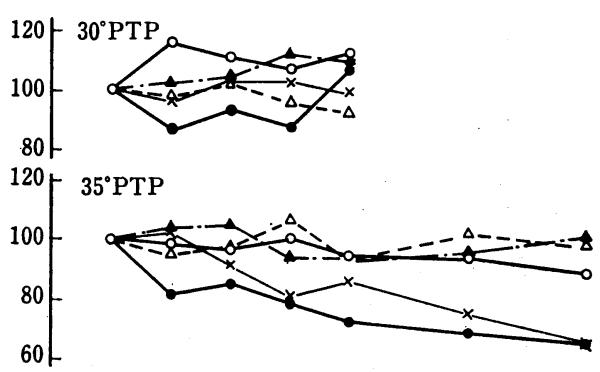

120 - $30^{\circ}$ Strip
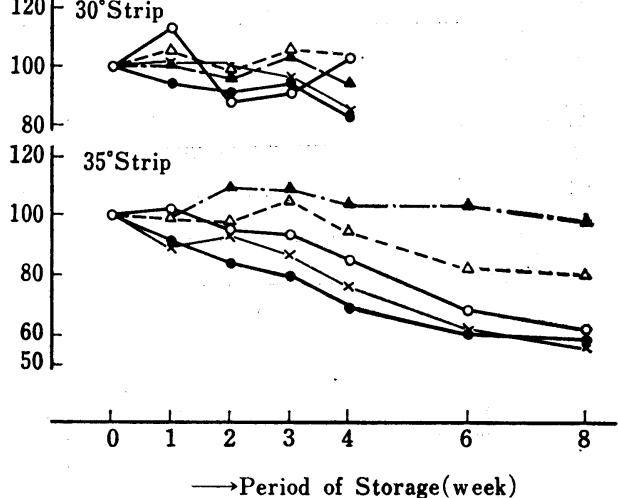

$\longrightarrow$ Period of Storage(week)

$\multimap$ Amylase $\multimap$ Lipase $\Delta--\Delta$ Protease $(\mathrm{pH} 3)$

L. Protease $(\mathrm{pH} 7) \quad x \longrightarrow$ Cellulase

Fig. 5. Change of Activities through the Storage at $30^{\circ}$ and $35^{\circ}$

定で 8 週間後も余り低下はみられなかったが，35保存 では 4 週間後から一部の酵素活性はPTP, バラの順に次 第に低下した。

5. 溶出試驗 リパーゼの溶出活性は A C , P T とも に30，35保存および PTP， バラ状態それぞれの力価 にしたがって低下はしたが, 溶出パターンには余り変化 はみられなかった。

Fig. 6 は $30^{\circ}, 35^{\circ}$ 保存における A C , P T 一ゼ (pH7.0) の溶出活性である. A C は力価も溶出パタ ーンもほとんど変化が認められなかった．P T は力価は 余り変わらなかったが $\mathrm{pH} 5.0$ 溶出液における溶出パター ンに変化がみられた. 溶出活性の立.ち上りが PTP $30^{\circ} 3$ 週間後にはすでに 30 分早くなり, PT P $30^{\circ} 4$ 週間, バラ $30^{\circ} 2$ 週間, PTP $35^{\circ} 2,4$ 週間も同様のパターンであっ た.さらにバラ $30^{\circ} 4$ 週間, PTP $35^{\circ} 8$ 週間, バラ $35^{\circ}$ $2,4,8$ 週間後ではより早くなり, A C に近似した溶出 パターンとなり腸溶皮膜の耐酸性の劣化が推測された.

\section{結福}

市販総合消化酵素カプセル剂の 6 製剤についてパック
状態で大約製造後30カ月室温に保存した結果, 重量, 外 観に変化はみられなかったが， S Eのカプセルの溶解性 に少し変化が現われ， S E , S T, S V の酵素活性の一部 が低下傾向にあり，また S E , T E , P T の腸溶皮膜の劣 化がうかがわれた. PTP 状態で室温に 1 年間保存した 場合には, いずれる内容物がやや濃色化し特異臭が強く なり， A C, P T の重量にやや増加がみられ， S E, $\mathrm{S} \mathrm{T}, \mathrm{S} V$ Vカプセルの溶解性が変化した. また S E, S T, S V の酵素活性の低下と, S E, T E, P T の腸溶 皮膜の劣化がみられ，ともにパック保存時よりもその程 度は大きかった. 初めから腸溶皮膜の溶解性の低かった $\mathrm{S} \mathrm{T}$ と耐酸性のやや弱かった A C は皮膜には顕著な変化 はらかがわれなかった。

吸湿, 外観, カプセルの崩壊・溶解性, 酵素活性, 溶 出性, 腸溶皮膜の耐酸・腸溶性等の劣化は製剂により異な っていたが，その変化の程度はパック保存よりむPTP 保存の方が大きかった. A C , P Tについて PTP とバ ラの状態で $30^{\circ}, 80 \% \mathrm{R} \mathrm{H}$ および $35^{\circ}, 80 \% \mathrm{R} \mathrm{H}$ で 48 週間の保存試験を行った結果では，P Tが $35^{\circ}$ 保存でバ ラ 3 週間, PTP 4 週間後からカプセル阂の外観変化が認 


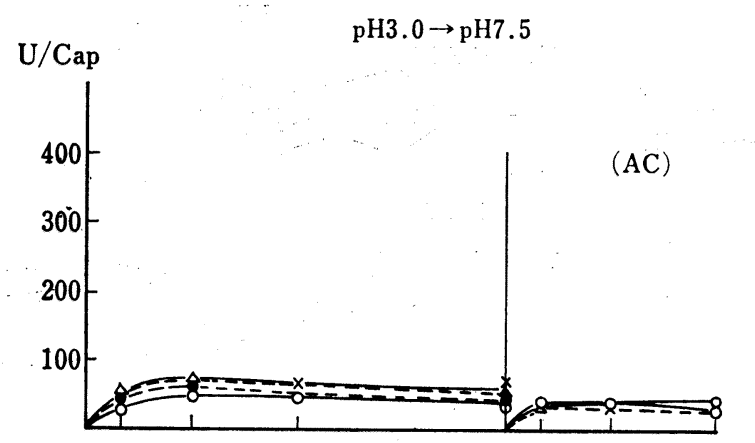

pH5.0
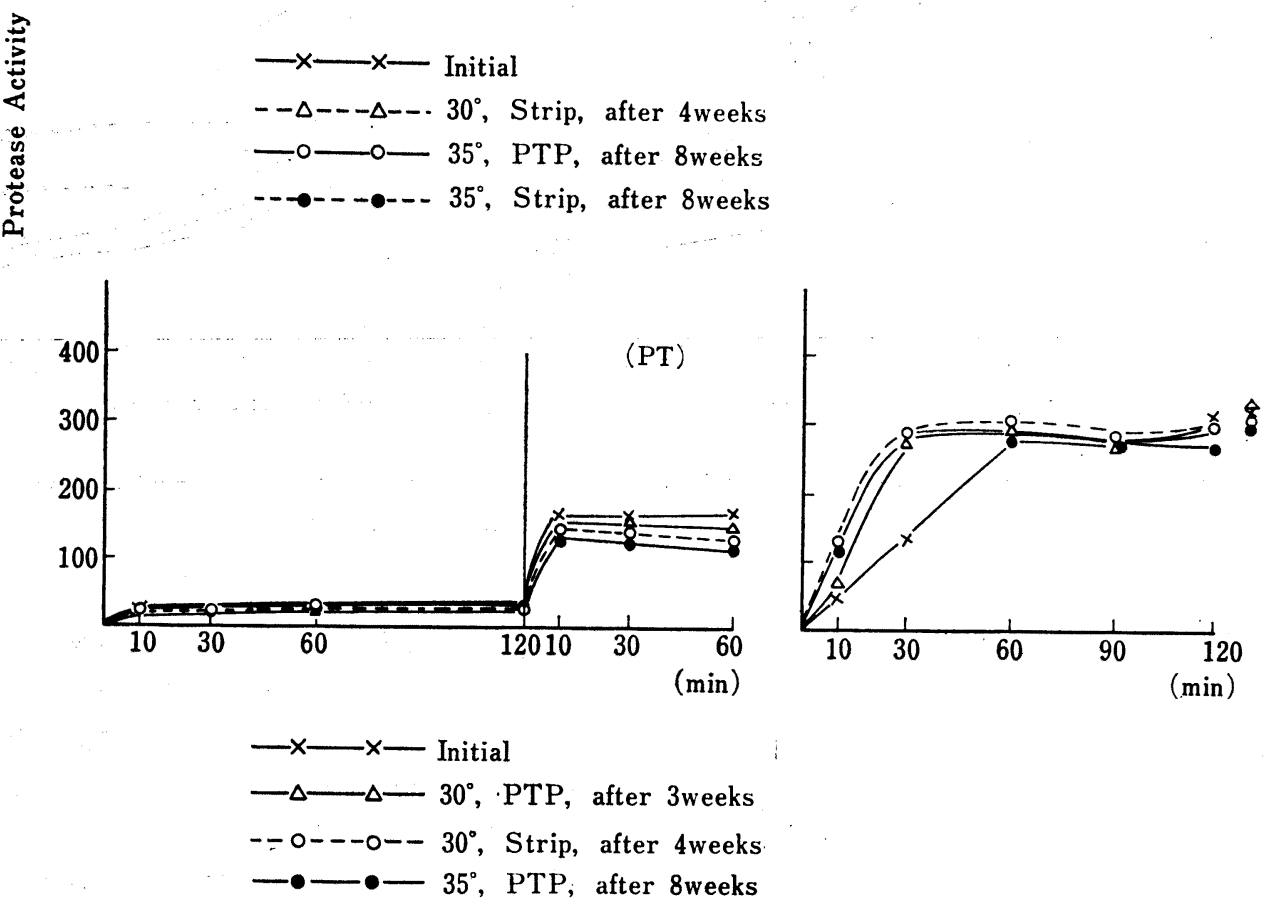

Fig. 6. Change of the Dissolution Curves of Protease(pH7.0) through the Storage at $30^{\circ}$ and $35^{\circ}$

められ， AC， PA とも PTP ょりバラの方が，バラでは $30^{\circ}$ 上り $35^{\circ}$ の方が吸湿が多く, 内容物は濃色化し特異臭 が增加した. $35^{\circ} 6$ 週間後にはA C, P T のバラ, PTP保 存ともカプセル自体の溶解性が幾分変化した. 酵素活性 は $30^{\circ} 4$ 週間は A C, P T のバラ, PTP 状態ともはとん

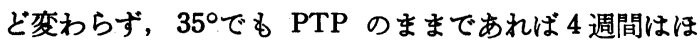
ぼ安定と考えられたが，バラにすると 4 週間後位から一 部活性が低下し始めた。

腸容皮膜は耐酸性の良好であった P Tで $30^{\circ}$ 保存では バラで 2 週間, PTP で 3 週間で劣化が始まり, $35^{\circ}$ 保存 ではさらに促進された．本試験は相対湿度を一定として
温度差による相違を検討したが，高温の場合には水蒸気 圧も高くなるので必然的にその影響をうけていると考え られ，PTP のままでも高温多湿状態で夏期を経過させ ることは品質の劣化を促し好ましくないと思われる。

\section{文塥}

1）永瀬一郎, 藤代とし, 岡本尚子：病院薬学, 2 , 256 (1977).

2）永瀬一郎, 藤代とし, 岡本尚子: 病院薬学, 2 , 262 (1977).

3）永瀬一郎, 藤代とし, 岡本尚子: 病院薬学, 4, 62 (1978). 
4) 杉浦 宿, 小木曾太郎, 棚橋濐行: 㿬鼻薬科大学 紀要, 15, 45 (1965).

5）杉浦 衛, 小木曾太郎, 中野忠史：薬剤学，28， 247 (1968).

6）神代 明, 藤升聡了, 越当紀子, 中野俊一：九州 薬学会会報, 25・26, 9 (1972).

7) 日本化学会編：実験化学俩座，24, 生物化学II, 282, 丸善 (1958).

8）汇上不二:夫ら編 : 標準牛化学実験，233, 文光堂 (1953).
9）赤堀四郎編：酵素研究法, 2, 240, 朝倉書店(1956).

10）江上不二夫ら䋧：標準生化学実験，207, 文 光 堂 (1953).

11）山田浩一, 太田安英, 町田晴夫：農芸化学, 36, 860 (1962).

12) T. Momose, A. Inaba, Y. Mukai, M. Watanabe : Talanta, 4, 33 (1960).

13）百瀬 勉，向井良子，河辺節子：臨床検查，5， 107 (1961).

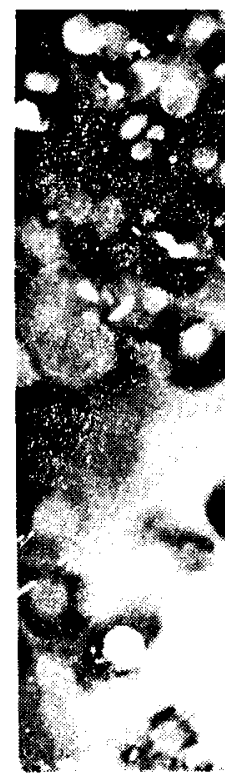

通底注が追加されました!

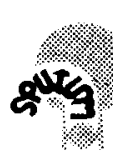

消炎酵素剤

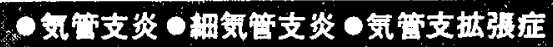

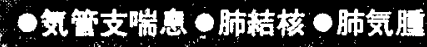
4.

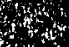
int

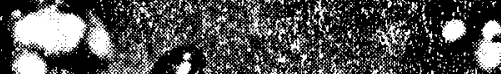
$(y+2)$ $(-\infty)$

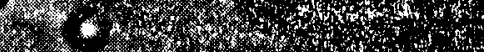

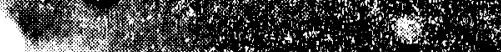
$4+\infty, \infty$

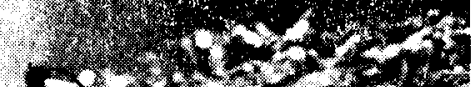
(2)

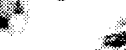

,
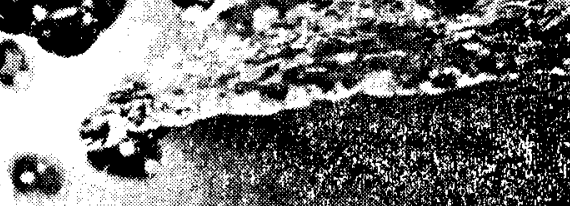

18

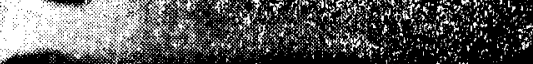

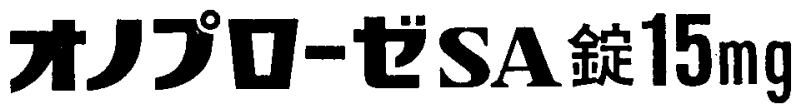

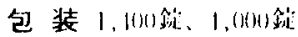

薬価基準（15my） 1 锆 75.90
適应症

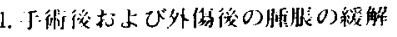
※2. 次の疾患の愘接喀出困難

気管支炎、湅気管支资、気管支拡張症、 気管支喘息、肺結核、肺文缰 (必進加効能)

用法・用量

ヒアプロービSとして、通常成人 1 问 10

〜15mgを1113〜4间每食後打よび就转 问に絴比投少する。

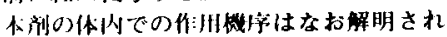
ない悠も多く、また、用最、効果の関䋆も 必ずしも明らかにされていない。従って 湤然と投りおすべきでない。

\section{使用上の注意}

・次の患者には䐜典に投与すること。

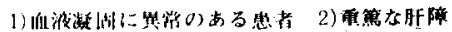

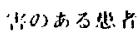

- 副作 用

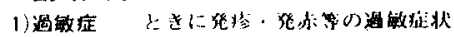

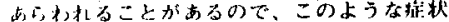

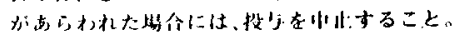

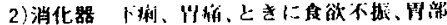

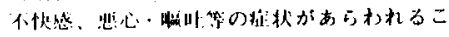
足が吉为。

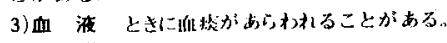
- 相互作用

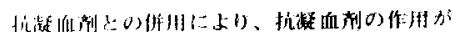

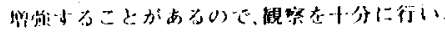

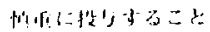

爵。野薬品工業株式会社 大阪市束区渞修町? 丁目 14 